\title{
Factors controlling prostaglandin production by guinea-pig endometrial cells
}

\author{
E. K. Naderali* and N. L. Poyser ${ }^{\dagger}$ \\ Department of Pharmacology, University of Edinburgh Medical School, 1 George Square, Edinburgh, \\ EH8 9JX, UK
}

\begin{abstract}
The main cell type in the guinea-pig endometrium responsible for prostaglandin ( $P G) F_{2 a}$ production and some of the intracellular mechanisms responsible for $\mathrm{PGF}_{2 u}$ synthesis in this cell type have been investigated. The glandular epithelial cells and not the stromal cells were found to be the main prostaglandin forming cells in the endometrium. A23187 (a calcium ionophore), phospholipase $A_{2}$ and melittin (an activator of endogenous phospholipase $A_{2}$ ) increased $\mathrm{PGF}_{2 \alpha}$ output from the glandular epithelial cells, although only the action of melittin was specific to this cell type. Phospholipase $\mathrm{A}_{2}$ also increased the intracellular free calcium concentration in both cell types by an action largely dependent upon the presence of extracellular calcium. Protein synthesis inhibitors (actinomycin D, cycloheximide and puromycin), oestradiol, progesterone and aristolochic acid (an inhibitor of phospholipase $A_{2}$ ) reduced $\mathrm{PGF}_{2 \alpha}$ output from the glandular epithelial cells, although only the inhibitory action of aristolochic acid was specific. Protein synthesis inhibitors also reduced PGF $\mathrm{F}_{2 \alpha}$ output from stromal cells, and the outputs of $\mathrm{PGE}_{2}$ and 6-keto-PGF $\mathrm{PF}_{11}$ from both cell types. The steroid hormones also reduced $\mathrm{PGE}_{2}$ output from stromal cells. The findings indicate that $\mathrm{PGF}_{2 u}$ production by the glandular epithelial cells is dependent upon fresh protein synthesis and the activity of endogenous phospholipase $A_{2}$ (which is a calcium-requiring enzyme).
\end{abstract}

\section{Introduction}

Prostaglandin (PG) $\mathrm{F}_{2 u}$ produced by the uterus is responsible for regression of corpora lutea in the guinea-pig and, therefore, the regulation of oestrous cycle duration (see Poyser, 1995). It is clear that the endometrium in the uterus is the source of PGF $_{2 u}$ (Butcher et al., 1962; Leaver and Seawright, 1982; Poyser, 1983a; Riley and Poyser, 1987a). Various factors (for example, regulators of phospholipase $A_{2}$ activity, ovarian steroid hormones, protein synthesis inhibitors) modulate endometrial $\mathrm{PGF}_{2 *}$ synthesis in the guinea-pig (Leaver and Seawright, 1982; Riley and Poyser, 1987a, b, 1989; Johnson and Poyser, 1991). The endometrium consists of two main cell types, namely epithelial cells and stromal cells. This study has investigated which is the main endometrial cell type for PG synthesis, and whether PG production by the two cell types in the guinea-pig is under different control.

\section{Materials and Methods}

\section{Materials}

Nutrient Mixture F-10 Ham (with Hepes), Hank's Balanced Salt Solution, streptomycin, trypan blue, amphotericin B,

*Present address: Department of Physiology, University of Liverpool, Crown Street, Liverpool, L69 3BX.

${ }^{+}$Correspondence.

Received 13 May 1996. actinomycin $\mathrm{D}$, collagenase Type 1 , aristolochic acid, cycloheximide, PLA (from Naja naja venom), A23187, melittin, puromycin, oestradiol and progesterone were purchased from Sigma Chemical Co., Poole, Dorset. Newborn calf serum and L-glutamine were purchased from Flow Laboratories, Irvine. Penicillin $G$ potassium salt was purchased from ICN Pharmaceuticals Ltd, Thame, Oxfordshire.

\section{Methods}

Guinea-pigs (600-900 g) were examined daily and a vaginal smear was taken when the vagina was open. Day 1 of the oestrous cycle was taken as the day preceding the postovulatory influx of leucocytes when cornification was at a maximum. All guinea-pigs had exhibited three ovarian cycles of normal duration before being used on day 7 or day 15 of the cycle. Four guinea-pigs on day 7 were used in each of Expts 1 to 3 (i.e. $n=4$ ), and three guinea-pigs on each of days 7 and 15 were used in Expt 4 (i.e. $n=3$ ). Each guinea-pig was killed by stunning and excising the neck. The uterus was removed and divided into its two uterine horns. Each horn was 'opened' by cutting longitudinally, and the endometrium was carefully cut away in small pieces from the myometrium by using a pair of fine scissors. This technique results in $>85 \%$ separation of the two tissues (Leaver and Poyser, 1981). The endometrial cells were dissociated by the method of Stayaswaroop et al. (1979) as modified by Chaminadas et al. (1986). In summary, the pieces of endometrium were chopped into small fragments and placed 
in $10 \mathrm{ml}$ Nutrient Mixture F-10 Ham containing Hepes $\left(20 \mathrm{mmol} \mathrm{l}^{-1}\right), 30 \%$ heat-treated new born calf serum, collagenase type $1\left(2 \mathrm{mg} \mathrm{ml}^{-1}\right)$, L-glutamine ( $\left.10 \mathrm{mmol} \mathrm{l}^{-1}\right)$, amphotericin B $\left(2.5 \mu \mathrm{g} \mathrm{ml}^{-1}\right)$, penicillin (100 $\left.\mathrm{U} \mathrm{ml}^{-1}\right)$ and streptomycin $\left(100 \mu \mathrm{g} \mathrm{ml}^{-1}\right)$. The tissue was incubated at $37^{\circ} \mathrm{C}$ with shaking, and the tissue fragments produced were disrupted further by gentle, repeated pipetting every $15 \mathrm{~min}$. The extent of digestion was monitored periodically by examining a small volume of the suspension under an inverted microscope. After adequate cell dispersion had been obtained, the remaining tissue fragments were collected by sedimentation and discarded. The digestion process took approximately $2 \mathrm{~h}$. The supernatant cell suspension was centrifuged at $100 \mathrm{~g}$ for $5 \mathrm{~min}$. The supernatant (containing stromal cells) was removed, and the pellet containing glandular epithelial cells was twice washed and centrifuged at $100 \mathrm{~g}$ for $5 \mathrm{~min}$. The final pellet obtained contained approximately $95 \%$ glandular epithelial cells and $5 \%$ stromal cells. The supernatant containing most of the stromal cells was centrifuged at $400 \mathrm{~g}$ for $10 \mathrm{~min}$, and a pellet of stromal cells was obtained. There was no detectable contamination of the stromal cells with glandular epithelial cells.

In Expts I to 3, the glandular epithelial cells and stromal cells were each resuspended in $30-40 \mathrm{ml}$ Nutrient Mixture F-10 Ham containing Hepes (20 mmol $\left.\mathrm{I}^{-1}\right)$, L-glutamine $(10 \mathrm{mmol}$ $\mathrm{l}^{-1}$ ), amphotericin $\mathrm{B}\left(2.5 \mu \mathrm{g} \mathrm{ml}^{-1}\right)$, penicillin (100 $\left.\mathrm{U} \mathrm{ml}^{-1}\right)$ and streptomycin $\left(100 \mu \mathrm{g} \mathrm{ml}^{-1}\right)$. Aliquots $(2.5 \mathrm{ml})$ of the cell suspension were dispersed into an adequate number of the wells of a cell culture plate. The glandular epithelial cell suspensions contained $2.3 \times 10^{3}$ to $4.5 \times 10^{3}$ cells $\mathrm{ml}^{-1}$, and the stromal cell suspension contained $2.2 \times 10^{5}$ to $5.6 \times 10^{5}$ cells $\mathrm{ml}^{-1}$. The cell culture plates were incubated at $37^{\circ} \mathrm{C}$ in a humified atmosphere of $5 \% \mathrm{CO}_{2}$ and $95 \%$ air. After $24 \mathrm{~h}$ of culture, the glandular epithelial cells had lost their shapes and had become flattened to form a monolayer. Stromal cells became attached to the plastic surface and, after $48 \mathrm{~h}$ of culture, a confluent layer of cells was formed. The medium in each well was changed every $72 \mathrm{~h}$, and the cells were cultured for 6 days before being used in Expts 1 to 3 .

In each experiment, the cells were cultured for a further $24 \mathrm{~h}$ in the absence and presence of treatments as outlined below. The culture medium was changed after 2,8 and $24 \mathrm{~h}$, and the samples of medium obtained were stored at $-20^{\circ} \mathrm{C}$. The amounts of $\mathrm{PGF}_{2 u^{\prime}} \mathrm{PGE}_{2}$ and 6-keto-PGF ${ }_{1 u}$ in each sample were measured, without extraction, by radioimmunoassay. Cell viability at the time of plating and at the end of culture was determined using a trypan blue exclusion method. To $0.1 \mathrm{ml}$ of a cell suspension prepared in Hank's Balanced Salt Solution was added $0.4 \mathrm{ml}$ of $0.4 \%(\mathrm{w} / \mathrm{v})$ Trypan blue solution. After $10 \mathrm{~min}$, the cells were washed and then monitored in a haemocytometer. Cell viability at the time of plating was $>98 \%$ and after culture was $>95 \%$.

In Expts 1 to 3, two wells containing each cell type from each animal were untreated (controls). In Expt 1, the remaining cells of each type from each animal were treated in duplicate with phospholipase (PL) $\mathrm{A}_{2}\left(2 \mathrm{U} \mathrm{ml}^{-1}\right)$ or the calcium ionophore, A23187 ( $1 \mu \mathrm{g} \mathrm{ml}^{-1}$ ). In Expt 2, the remaining cells of each type were treated in duplicate with oestradiol $(3.7 \mu \mathrm{mol}$ $\left.\mathrm{l}^{-1}\right)$, progesterone $\left(3.2 \mu \mathrm{mol} \mathrm{l^{-1 }}\right)$, melittin $\left(2 \mu \mathrm{g} \mathrm{ml}^{-1}\right)$ or aristolochic acid $\left(50 \mu \mathrm{mol} l^{-1}\right)$. In Expt 3 , the remaining cells were treated in duplicate with actinomycin $\mathrm{D}$ (10 and $50 \mu \mathrm{g}$ $\mathrm{ml}^{-1}$ ), cycloheximide (10 and $50 \mu \mathrm{g} \mathrm{ml}^{-1}$ ) and puromycin (10 and $\left.50 \mu \mathrm{g} \mathrm{ml}^{-1}\right)$. The concentration of aristolochic acid used inhibits PLA $\mathrm{P}_{2}$ activity in human neutrophils (Rosenthal et al., 1989), and the concentrations of the other compounds used increase or inhibit PG output from the guinea-pig superfused uterus or cultured endometrium (Poyser and Bryden, 1983; Poyser, 1987; Riley and Poyser, 1987b, 1989; Johnson and Poyser, 1991). The average of each set of duplicate results was used for each animal.

In Expt 4, the suspensions of glandular epithelial cells and stromal cells were not incubated. After preparation, the cells were washed twice in Krebs solution (for composition: see Mitchell et al., 1977) or in calcium-depleted Krebs solution (from which the calcium chloride had been omitted) both buffered with Hepes $\left(20 \mathrm{mmol} \mathrm{l}^{-1}\right)$ at $\mathrm{pH} 7.4$. After centrifugation (at 100 or $400 \mathrm{~g}$ for 5 or $10 \mathrm{~min}$, as appropriate), the cells were resuspended in the appropriate Krebs solution and loaded with fura-2 acetoxymethyl ester (fura-2AM) by incubating for $30 \mathrm{~min}$ at room temperature. Cells were then washed and centrifuged, resuspended in the appropriate Krebs solution, and left to stand for a further 30 min to allow the intracellular fura-2AM to hydrolyse to fura-2. The cells were then washed, resuspended in calcium-containing or calcium-depleted Krebs solution, and transferred to a quartz cuvette maintained at $37^{\circ} \mathrm{C}$. Fluoresence was measured in the absence and presence of $\mathrm{PLA}_{2}$ (1-10 $\mathrm{U} \mathrm{ml}^{-1}$ added cumulatively) in a Shimadzo spectrofluorophotometer (Type RF-5000) at $505 \mathrm{~nm}$ with alternate excitation at $340 \mathrm{~nm}$ and $380 \mathrm{~nm}$. The intracellular free calcium concentration $\left(\left[\mathrm{Ca}^{2+}\right]_{\mathrm{i}}\right)$ was calculated using the equation of Grynkiewicz et al. (1985):

$$
\left[\mathrm{Ca}^{2+}\right]_{\mathrm{j}}=k_{\mathrm{d}} \times b \times\left(R-R_{\min }\right) /\left(R_{\max }-R\right)
$$

where, $k_{d}$ is the dissociation constant for the fura-2- $\mathrm{Ca}^{2+}$ complex, and was assumed to be $225 \mathrm{nmol} 1^{-1}$ at $37^{\circ} \mathrm{C}$ (Grynkiewicz et al., 1985; Buchan and Martin, 1991); $b$ is the ratio of the $380 \mathrm{~nm}$ signals in $\mathrm{Ca}^{2+}$-depleted and $\mathrm{Ca}^{2+}$. containing Krebs solution; $R$ is the ratio of the fluorescence at $340 \mathrm{~nm}$ to that at $380 \mathrm{~nm}$; and $R_{\max }$ and $R_{\min }$ are the maximum and minimum fluorescence ratios obtained in the presence of ionomycin ( $10 \mu \mathrm{mol} \mathrm{l}^{-1}$; a calcium ionophore) and EGTA (30 $\mathrm{mol} \mathrm{l}^{-1}$; a calcium chelator), respectively.

\section{Details of radioimmunoassay}

$\mathrm{PGF}_{2 u^{\prime}}, \mathrm{PGE}_{2}$ and 6-keto-PGF $\mathrm{F}_{10}$ were measured using antibodies raised in this laboratory. The crossreactivities have been reported by Poyser (1987). The standard PG solutions used in the assay contained an amount of culture medium equivalent to that used for the samples. The intra-assay and inter-assay coefficients of variation were $<12 \%$ for each assay. The detection limit was $30 \mathrm{pg}$ PG per assay tube for the three assays.

\section{Statistical analysis}

The results were analysed by one-way analysis of variance (ANOVA), the paired $t$ test or Student's $t$ test as appropriate. 
Table 1. Effects of phospholipase $\mathrm{A}_{2}\left(\mathrm{PLA}_{2} ; 2 \mathrm{U} \mathrm{ml}^{-1}\right)$ and $\mathrm{A} 23187\left(1 \mu \mathrm{g} \mathrm{ml}^{-1}\right)$ on mean \pm SEM $(n=4)$ outputs of prostaglandin (PG) $F_{2, u^{\prime}} P C_{2}$ and 6-keto-PGF ${ }_{1 u}$ from glandular epithelial cells and stromal cells of guinea-pig endometrium during three consecutive periods of cell culture

\begin{tabular}{|c|c|c|c|c|c|c|}
\hline \multirow[b]{3}{*}{ Treatment } & \multicolumn{6}{|c|}{ PG output (pg (1000 cell) $)^{-1} \mathrm{~h}^{-1}$ ) } \\
\hline & \multicolumn{6}{|c|}{ Culture period } \\
\hline & Glandular & Stromal & Glandular & Stromal & Glandular & Stromal \\
\hline \multicolumn{7}{|l|}{$\mathrm{PGF}_{2 u}$} \\
\hline Control & $103.1 \pm 7.0$ & $0.42 \pm 0.10$ & $51.2 \pm 16.3$ & $0.20 \pm 0.07$ & $28.9 \pm 4.1$ & $0.10 \pm 0.02$ \\
\hline $\mathrm{PLA}_{2}$ & $100.4 \pm 4.1$ & $0.47 \pm 0.09$ & $52.4 \pm 13.2$ & $0.22 \pm 0.04$ & $50.2 \pm 8.7^{\dagger}$ & $0.17 \pm 0.04^{+}$ \\
\hline A23187 & $180.6 \pm 7.3^{\dagger}$ & $0.55 \pm 0.09$ & $29.1 \pm 7.6$ & $0.12 \pm 0.02$ & $9.4 \pm 1.8^{*}$ & $0.04 \pm 0.01^{*}$ \\
\hline \multicolumn{7}{|l|}{$\mathrm{PGE}_{2}$} \\
\hline Control & $112.4 \pm 21.9$ & $1.02 \pm 0.11$ & $34.2 \pm 4.8$ & $0.37 \pm 0.02$ & $13.2 \pm 1.1$ & $0.16 \pm 0.01$ \\
\hline $\mathrm{PLA}_{2}$ & $176.5 \pm 35.2^{\dagger}$ & $1.63 \pm 0.11^{+}$ & $63.9 \pm 13.8^{\dagger}$ & $0.56 \pm 0.04^{+}$ & $34.4 \pm 9.6^{\dagger}$ & $0.24 \pm 0.01^{+}$ \\
\hline A23187 & $134.2 \pm 51.1$ & $1.03 \pm 0.07$ & $30.2 \pm 3.9$ & $0.32 \pm 0.02$ & $20.2 \pm 6.1$ & $0.16 \pm 0.01$ \\
\hline \multicolumn{7}{|c|}{ 6-keto-PGF ${ }_{I u}$} \\
\hline Control & $57.7 \pm 5.2$ & $0.49 \pm 0.09$ & $18.9 \pm 2.8$ & $0.17 \pm 0.02$ & $9.4 \pm 2.1$ & $0.06 \pm 0.01$ \\
\hline $\mathrm{PLA}_{2}$ & $72.2 \pm 11.3$ & $0.51 \pm 0.07$ & $22.1 \pm 2.7$ & $0.18 \pm 0.02$ & $13.2 \pm 1.8^{\dagger}$ & $0.09 \pm 0.01^{+}$ \\
\hline A23187 & $62.3 \pm 10.7$ & $0.42 \pm 0.05$ & $13.2 \pm 1.6$ & $0.10 \pm 0.01^{*}$ & $7.2 \pm 0.7$ & $0.05 \pm 0.01^{*}$ \\
\hline
\end{tabular}

* Significantly $(P<0.05)$ lower than corresponding control value.

${ }^{\dagger}$ Significantly $(P<0.05)$ higher than corresponding control value.

\section{Results}

In Expts 1 to 3 the basal, initial outputs of $\mathrm{PGF}_{2 \alpha^{\prime}} \mathrm{PGE}_{2}$ and 6-keto-PGF ${ }_{1 \alpha}$ were between 95 - and 450 times higher from glandular epithelial cells than from stromal cells (Tables 1-3). The basal outputs of the three prostaglandins significantly $(P<0.05)$ declined with time over the $24 \mathrm{~h}$ culture period.

\section{Experiment 1: effects of $P L A_{2}$ and $A 23187$ on $P G$ output}

On the glandular cells, PLA 2 significantly $(P<0.05)$ increased $\mathrm{PGF}_{2 u}$ output 1.7-fold after $24 \mathrm{~h}, \mathrm{PGE}_{2}$ output 1.6- to 2.6-fold after 2,8 and $24 \mathrm{~h}$, and 6-keto-PGF $1 a$ 1.2-fold after $24 \mathrm{~h}$ of culture (Table 1$)$. A23187 significantly $(P<0.05)$ increased the output of $\mathrm{PGF}_{2 \alpha} 1.7$-fold after $2 \mathrm{~h}$ but significantly $(P<0.05)$ decreased $\mathrm{PGF}_{2 \alpha}$ output by $69 \%$ after $24 \mathrm{~h}$ of culture. A23187 had no significant effect on the outputs of $\mathrm{PGE}_{2}$ and 6-keto-PGF ${ }_{\mathrm{I} \alpha}$ from glandular epithelial cells (Table 1).

On stromal cells, $P_{2} A_{2}$ significantly $(P<0.05)$ increased the outputs of $\mathrm{PGF}_{2 \alpha}$ and 6-keto-PGF 14 1.7-fold and 1.4-fold, respectively, after $24 \mathrm{~h}$, and the output of $\mathrm{PGE}_{2} 1.5$ - to 1.6-fold after 2,8 and $24 \mathrm{~h}$ of culture (Table 1). A23187 significantly $(P<0.05)$ increased $\mathrm{PGF}_{2 \alpha}$ output 1.3 -fold after $2 \mathrm{~h}$, but significantly $(P<0.05)$ decreased $\mathrm{PGF}_{2 \alpha}$ output by $58 \%$ after $24 \mathrm{~h}$ of culture. A23187 also significantly $(P<0.05)$ decreased the output of 6-keto-PGF ${ }_{1 \mu}$ by 22 to $39 \%$ after 8 and 24 h. A23187 had no effect on $\mathrm{PGE}_{2}$ output from stromal cells (Table 1).

Experiment 2: effects of oestradiol, progesterone, melittin and aristolochic acid on $P G$ output

Oestradiol and progesterone significantly $(P<0.05)$ decreased PGF $2 u$ output by 28 to $41 \%$ from glandular epithelial cells, and $\mathrm{PGE}_{2}$ output by $15 \%$ from stromal cells after $8 \mathrm{~h}$ of culture. Oestradiol also significantly $(P<0.05)$ decreased the output of $\mathrm{PGF}_{20}$ by $37 \%$ from glandular epithelial cells after $24 \mathrm{~h}$ of culture (Table 2). Melittin significantly $(P<0.05)$ increased the outputs of $\mathrm{PGF}_{2 a^{\prime}} \mathrm{PGE}_{2}$ and 6-keto-PGF $\mathrm{PG}_{1 u}$ up to 1.6-fold after $2 \mathrm{~h}$ of culture, and $\mathrm{PGF}_{2 u^{\prime}}$ output 1.4-fold after $24 \mathrm{~h}$ of culture from glandular epithelial cells. Melittin had no effect on the outputs of PGF $2 u^{\prime} P_{2} E_{2}$ and 6-keto-PGF $1 u$ from stromal cells (Table 2).

Aristolochic acid significantly $(P<0.05)$ inhibited $P G_{2 u}$ output by 52 to $56 \%$ from glandular epithelial cells after 8 and $24 \mathrm{~h}$ of culture. It had no effect on the outputs of $\mathrm{PGE}_{2}$ and 6-keto-PGF ${ }_{1 \mu}$ from glandular epithelial cells. Aristolochic acid significantly $(P<0.05)$ increased $\mathrm{PGE}_{2}$ output from stromal cells by 1.2 -fold after $2 \mathrm{~h}$ of culture, but had no effect on the outputs of $\mathrm{PGF}_{2 \alpha}$ and 6-keto-PGF ${ }_{1 \alpha}$ from stromal cells (Table 2).

\section{Experiment 3: effects of protein synthesis inhibitors on $P G$ output}

Cycloheximide and puromycin (both at 10 and $50 \mu \mathrm{g} \mathrm{ml}^{-1}$ ) significantly $(P<0.05)$ inhibited the output of $\mathrm{PGF}_{2 \alpha}$ from glandular epithelial cells by 26 to $45 \%$ after $2 \mathrm{~h}$, by 62 to $84 \%$ after $8 \mathrm{~h}$, and by 84 to $90 \%$ after $24 \mathrm{~h}$. Actinomycin D (10 and $50 \mu \mathrm{g} \mathrm{ml}^{-1}$ ) significantly $(P<0.05)$ inhibited $\mathrm{PGF}_{2 u}$ output from glandular epithelial cells by $68 \%$ after $8 \mathrm{~h}$ and by $81 \%$ after $24 \mathrm{~h}$ (Table 3). PGE output from glandular epithelial cells was significantly $(P<0.05)$ inhibited between 18 and $28 \%$ by cycloheximide $\left(10 \mu \mathrm{g} \mathrm{ml}^{-\mathrm{I}}\right.$ ) after $2 \mathrm{~h}$, by actinomycin $\mathrm{D}$ (10 and $50 \mu \mathrm{g} \mathrm{ml}^{-1}$ ) and puromycin $\left(50 \mu \mathrm{g} \mathrm{ml}^{-1}\right)$ after $8 \mathrm{~h}$, and by puromycin $\left(10 \mu \mathrm{g} \mathrm{ml}^{-1}\right.$ ) after $24 \mathrm{~h}$ (Table 3 ). The output

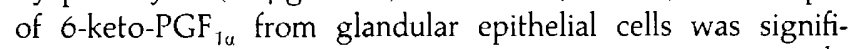
cantly $(P<0.05)$ inhibited by actinomycin $\mathrm{D}\left(10 \mu \mathrm{g} \mathrm{m} \mathrm{m}^{-1}\right)$, 
Table 2. Effects of oestradiol $\left(3.7 \mu \mathrm{mol} \mathrm{l} \mathrm{l}^{-1}\right)$, progesterone $\left(3.2 \mu \mathrm{mol} \mathrm{l}^{-1}\right)$, melittin $\left(2 \mu \mathrm{g} \mathrm{ml} \mathrm{I}^{-1}\right)$ and aristolochic acid (Arist. acid; $\left.50 \mu \mathrm{mol} \mathrm{l}^{-1}\right)$ on mean $\pm \operatorname{SEM}(n=4)$ outputs of prostaglandin (PG) $\mathrm{F}_{2 \omega^{\prime}} \mathrm{PGE}_{2}$ and $6-\mathrm{keto} \mathrm{PGF}_{\mathrm{I} \alpha}$ from glandular epithelial cells and stromal cells of guinea-pig endometrium during three consecutive periods of cell culture

\begin{tabular}{|c|c|c|c|c|c|c|}
\hline \multirow[b]{4}{*}{ Treatment } & \multicolumn{6}{|c|}{ PG output (pg (1000 cell $\left.)^{-1} h^{-1}\right)$} \\
\hline & \multicolumn{6}{|c|}{ Culture period } \\
\hline & \multicolumn{2}{|c|}{$\mathrm{o}-2 \mathrm{~h}$} & \multicolumn{2}{|c|}{$2-8 \mathrm{~h}$} & \multicolumn{2}{|c|}{$8-24 \mathrm{~h}$} \\
\hline & Glandular & Stromal & Glandular & Stromal & Glandular & Stromal \\
\hline Oestradiol & $154.5 \pm 12.2$ & $0.34 \pm 0.06$ & $59.3 \pm 8.2^{*}$ & $0.11 \pm 0.01$ & $36.8 \pm 0.8^{*}$ & $0.05 \pm 0.01$ \\
\hline Progesterone & $196.2 \pm 25.8$ & $0.37 \pm 0.04$ & $73.4 \pm 11.6^{*}$ & $0.12 \pm 0.01$ & $55.2 \pm 2.7$ & $0.05 \pm 0.01$ \\
\hline Melittin & $272.1 \pm 57.1^{\dagger}$ & $0.39 \pm 0.05$ & $130.2 \pm 46.1$ & $0.12 \pm 0.02$ & $83.2 \pm 1.2^{\dagger}$ & $0.06 \pm 0.01$ \\
\hline Arist. acid & $154.3 \pm 28.6$ & $0.30 \pm 0.04$ & $44.4 \pm 9.8^{*}$ & $0.10 \pm 0.01$ & $28.4 \pm 7.9^{*}$ & $0.04 \pm 0.01$ \\
\hline \multicolumn{7}{|l|}{$\mathrm{PGE}_{2}$} \\
\hline Control & $163.1 \pm 14.2$ & $1.41 \pm 0.02$ & $72.1 \pm 14.2$ & $0.56 \pm 0.02$ & $27.8 \pm 2.7$ & $0.23 \pm 0.01$ \\
\hline \multicolumn{7}{|l|}{ 6-keto-PGF } \\
\hline Control & $117.3 \pm 10.1$ & $0.83 \pm 0.07$ & $50.8 \pm 7.8$ & $0.29 \pm 0.02$ & $21.1 \pm 3.8$ & $0.12 \pm 0.03$ \\
\hline Oestradiol & $116.5 \pm 9.8$ & $0.79 \pm 0.17$ & $44.2 \pm 8.7$ & $0.27 \pm 0.08$ & $18.1 \pm 1.7$ & $0.10 \pm 0.01$ \\
\hline Progesterone & $122.1 \pm 16.2$ & $0.82 \pm 0.14$ & $42.9 \pm 7.9$ & $0.26 \pm 0.05$ & $17.8 \pm 1.8$ & $0.09 \pm 0.01$ \\
\hline Melittin & $150.4 \pm 32.6^{\dagger}$ & $0.90 \pm 0.15$ & $47.2 \pm 9.6$ & $0.30 \pm 0.07$ & $25.2 \pm 7.2$ & $0.11 \pm 0.02$ \\
\hline Arist. acid & $114.3 \pm 22.2$ & $0.82 \pm 0.09$ & $48.1 \pm 9.9$ & $0.25 \pm 0.02$ & $19.1 \pm 2.8$ & $0.10 \pm 0.01$ \\
\hline
\end{tabular}

*Significantly $(P<0.05)$ lower than corresponding control value.

"Significantly $(P<0.05)$ higher than corresponding control value.

cycloheximide $\left(50 \mu \mathrm{g} \mathrm{ml}^{-1}\right)$ and puromycin $\left(50 \mu \mathrm{g} \mathrm{ml}^{-1}\right)$ after $2 \mathrm{~h}$ and by cycloheximide (10 $\mu \mathrm{g} \mathrm{ml}^{-1}$ ), actinomycin D (10 $\mu \mathrm{g}$ $\left.\mathrm{ml}^{-1}\right)$ and puromycin $\left(50 \mu \mathrm{g} \mathrm{ml}^{-1}\right)$ after $8 \mathrm{~h}$. By $24 \mathrm{~h}$, both concentration's of actinomycin $\mathrm{D}$, cycloheximide and puromycin significantly $(P<0.05)$ inhibited the output of 6-keto$\mathrm{PGF}_{10 \mathrm{x}}$ from glandular epithelial cells. The degree of inhibition ranged from 34 to $67 \%$ (Table 3 ).

On stromal cells actinomycin D, cycloheximide and puromycin $\left(10\right.$ and $\left.50 \mu \mathrm{g} \mathrm{ml}^{-\mathrm{I}}\right)$ significantly $(P<0.05)$ inhibited the outputs of $\mathrm{PGF}_{2 \alpha^{\prime}}, \mathrm{PGE}_{2}$ and 6-keto-PGF $\mathrm{PG}_{1 \alpha^{\prime}}$ except for cycloheximide $\left(50 \mu \mathrm{g} \mathrm{ml}^{-1}\right)$ which had no effect on $\mathrm{PGE}_{2}$ output during all three culture periods. In addition, puromycin $\left(10 \mu \mathrm{g} \mathrm{ml}^{-1}\right)$ and cycloheximide $\left(10 \mu \mathrm{g} \mathrm{ml}^{-1}\right)$ had no effect on $\mathrm{PGE}_{2}$ output during the first and the last periods of culture, respectively. The degree of inhibition ranged from 10 to $89 \%$ (Table 3).

\section{Experiment 4: effect of $\mathrm{PLA}_{2}$ on the intracellular free calcium concentration}

In the presence of extracellular calcium, PLA 2 significantly $(P<0.05)$ increased the intracellular free calcium concentration of day 7 and day 15 epithelial and stromal cells 16.8- to 54.4-fold (Fig. 1). In calcium-depleted medium $\mathrm{PLA}_{2}$ significantly $(P<0.05)$ increased the intracellular free calcium concentration in day 7 and day 15 epithelial cells and stromal cells 2.8 . to 10.3-fold although, owing to the large scatter of results, some of these increases were not significant on day 7 (Fig. 1). In the presence or absence of extracellular calcium, $\mathrm{PLA}_{2}$ ( 4 to $\left.10 \mathrm{U} \mathrm{ml}^{-1}\right)$ significantly $(P<0.05)$ increased the intracellular free calcium concentration to a greater extent in epithelial cells than in stromal cells obtained from day 15, but not day 7 , endometrium (Table 1).

\section{Discussion}

Prostaglandin output is approximately 100- to 500-fold higher from glandular epithelial cells than from stromal cells. This difference occurred during the 6 days of culture before using the cells (data not shown), and on the seventh day when the cells were treated. On this experimental day, PG output per hour from both cell types decreased during the $24 \mathrm{~h}$ period. This may be a consequence of the increasing time intervals between changes of culture medium with the resultant slowing down of PG synthesis as nutrients are used up. It is clear that the glandular epithelial cells produce considerably more $\mathrm{PGF}_{2 \alpha}$ than do the stromal cells and are therefore the source of the uterine luteolytic hormone in guinea-pigs. The epithelial cells have also been found to be the major endothelial cell type that synthesize $\mathrm{PGF}_{2 u}$ in rats, pigs, horses and cows (Peplow and Hurst, 1989; Zhang and Davis, 1991; Watson et al., 1992; Danet-Desnoyers et al., 1994). $\mathrm{PGE}_{2}$ was the major PG synthesized by stromal cells in the guinea-pig. 
Table 3. Effects of actinomycin D (Actin. D; 10 and $50 \mu \mathrm{g} \mathrm{ml}^{-1}$ ); cycloheximide (Cyclo.; 10 and $50 \mu \mathrm{g} \mathrm{ml}^{-1}$ ) and puromycin (Puromy; 10 and $50 \mu \mathrm{g} \mathrm{ml}^{-1}$ ) on mean $\pm \operatorname{sEM}(n=4)$ outputs of prostaglandin (PG) $\mathrm{F}_{2 \alpha^{\prime}} \mathrm{PGE}_{2}$ and 6-keto-PGF from glandular epithelial cells and stromal cells of guinea-pig endometrium during three consecutive periods of cell culture

\begin{tabular}{|c|c|c|c|c|c|c|}
\hline \multirow[b]{4}{*}{ Treatment } & \multicolumn{6}{|c|}{ PG output (pg (1000 cell) $)^{-1} h^{-1}$ ) } \\
\hline & \multicolumn{6}{|c|}{ Culture period } \\
\hline & \multicolumn{2}{|c|}{$0-2 h$} & \multicolumn{2}{|c|}{$2-8 \mathrm{~h}$} & \multicolumn{2}{|c|}{$8-24 \mathrm{~h}$} \\
\hline & Glandular & Stromal & Glandular & Stromal & Glandular & Stromal \\
\hline \multicolumn{7}{|l|}{$\mathrm{PGF}_{2 u}$} \\
\hline Control & $89.2 \pm 4.1$ & $0.42 \pm 0.01$ & $49.2 \pm 2.8$ & $0.15 \pm 0.09$ & $37.4 \pm 1.4$ & $0.072 \pm 0.003$ \\
\hline Actin. D 10 & $70.4 \pm 5.2$ & $0.30 \pm 0.02^{+}$ & $15.4 \pm 2.2^{\dagger}$ & $0.08 \pm 0.01^{\dagger}$ & $7.1 \pm 0.8^{\dagger}$ & $0.027 \pm 0.003^{\dagger}$ \\
\hline Actin. D 50 & $80.3 \pm 5.8$ & $0.29 \pm 0.02^{+}$ & $16.3 \pm 2.4^{\dagger}$ & $0.07 \pm 0.01^{\dagger}$ & $7.2 \pm 0.7^{\dagger}$ & $0.027 \pm 0.003^{\dagger}$ \\
\hline Cyclo. 10 & $52.3 \pm 5.9^{+}$ & $0.28 \pm 0.02^{\dagger}$ & $12.2 \pm 1.4^{+}$ & $0.08 \pm 0.01^{\dagger}$ & $4.1 \pm 0.3^{\dagger}$ & $0.026 \pm 0.003^{\dagger}$ \\
\hline Cyclo. 50 & $49.4 \pm 5.2^{4}$ & $0.29 \pm 0.01^{+}$ & $11.8 \pm 1.3^{+}$ & $0.09 \pm 0.01^{\dagger}$ & $5.2 \pm 0.4^{\dagger}$ & $0.024 \pm 0.001^{\dagger}$ \\
\hline Puromy. 10 & $66.1 \pm 4.2^{+}$ & $0.35 \pm 0.02^{+}$ & $19.2 \pm 2.6^{+}$ & $0.09 \pm 0.01^{\dagger}$ & $6.2 \pm 0.4^{\dagger}$ & $0.029 \pm 0.003^{\dagger}$ \\
\hline Puromy. 50 & $52.3 \pm 6.8^{\dagger}$ & $0.26 \pm 0.01^{+}$ & $8.2 \pm 0.4^{\dagger}$ & $0.07 \pm 0.01^{\dagger}$ & $4.9 \pm 0.6^{\dagger}$ & $0.024 \pm 0.002^{\dagger}$ \\
\hline \multicolumn{7}{|l|}{$\mathrm{PGE}_{2}$} \\
\hline Control & $113.2 \pm 12.1$ & $1.16 \pm 0.02$ & $35.3 \pm 1.8$ & $0.43 \pm 0.03$ & $18.2 \pm 1.2$ & $0.16 \pm 0.01$ \\
\hline Actin. D 10 & $96.4 \pm 7.8$ & $1.06 \pm 0.03$ & $29.2 \pm 1.8^{\dagger}$ & $0.33 \pm 0.01^{\dagger}$ & $17.4 \pm 1.9$ & $0.14 \pm 0.01^{+}$ \\
\hline Actin. D 50 & $89.8 \pm 5.9$ & $1.00 \pm 0.04^{\dagger}$ & $28.4 \pm 1.7^{\dagger}$ & $0.28 \pm 0.02^{\dagger}$ & $15.3 \pm 1.8$ & $0.13 \pm 0.01^{+}$ \\
\hline Cyclo. 10 & $88.2 \pm 6.2^{\dagger}$ & $0.98 \pm 0.02^{\dagger}$ & $30.1 \pm 3.9$ & $0.32 \pm 0.01^{\dagger}$ & $15.2 \pm 1.6$ & $0.14 \pm 0.02$ \\
\hline Cyclo. 50 & $120.2 \pm 12.1$ & $1.20 \pm 0.11$ & $39.2 \pm 3.1$ & $0.40 \pm 0.02$ & $17.4 \pm 2.1$ & $0.16 \pm 0.01$ \\
\hline Puromy. 10 & $106.8 \pm 4.8$ & $1.02 \pm 0.03$ & $36.2 \pm 5.8$ & $0.34 \pm 0.01^{\dagger}$ & $13.1 \pm 1.8^{+}$ & $0.13 \pm 0.01^{+}$ \\
\hline Puromy. 50 & $104.7 \pm 13.8$ & $0.95 \pm 0.04^{\dagger}$ & $26.8 \pm 3.7^{\dagger}$ & $0.31 \pm 0.02^{\dagger}$ & $13.9 \pm 1.9$ & $0.13 \pm 0.01^{\dagger}$ \\
\hline \multicolumn{7}{|l|}{ 6-keto-PGF } \\
\hline Control & $105.2 \pm 21.1$ & $0.99 \pm 0.04$ & $18.1 \pm 2.1$ & $0.49 \pm 0.14$ & $12.2 \pm 0.3$ & $0.18 \pm 0.04$ \\
\hline Actin. D. 10 & $48.9 \pm 2.1^{\dagger}$ & $0.68 \pm 0.04^{\dagger}$ & $9.7 \pm 1.6^{\dagger}$ & $0.12 \pm 0.02^{+}$ & $7.2 \pm 0.8^{+}$ & $0.04 \pm 0.01^{\dagger}$ \\
\hline Actin. D 50 & $86.5 \pm 25.5$ & $0.68 \pm 0.01^{\dagger}$ & $26.5 \pm 4.8$ & $0.10 \pm 0.02^{+}$ & $7.2 \pm 0.7^{\dagger}$ & $0.04 \pm 0.01^{\dagger}$ \\
\hline Cyclo. 10 & $86.0 \pm 29.6$ & $0.56 \pm 0.03^{\dagger}$ & $12.1 \pm 1.4^{\dagger}$ & $0.10 \pm 0.02^{\dagger}$ & $6.0 \pm 0.6^{+}$ & $0.08 \pm 0.02^{\dagger}$ \\
\hline Cyclo. 50 & $35.1 \pm 2.2^{\dagger}$ & $0.55 \pm 0.06^{\dagger}$ & $21.2 \pm 5.8$ & $0.10 \pm 0.01^{\dagger}$ & $4.1 \pm 0.3^{\dagger}$ & $0.04 \pm 0.01^{\dagger}$ \\
\hline Puromy. 10 & $93.2 \pm 24.2$ & $0.68 \pm 0.01^{\dagger}$ & $14.8 \pm 3.8$ & $0.14 \pm 0.01^{+}$ & $3.8 \pm 0.4^{\dagger}$ & $0.05 \pm 0.01^{\dagger}$ \\
\hline Puromy. 50 & $43.1 \pm 3.2^{\dagger}$ & $0.57 \pm 0.03^{\dagger}$ & $6.1 \pm 0.4^{\dagger}$ & $0.10 \pm 0.01^{+}$ & $4.7 \pm 0.5^{\dagger}$ & $0.04 \pm 0.01^{+}$ \\
\hline
\end{tabular}

${ }^{\dagger}$ Significantly $(\mathrm{P}<0.05)$ lower than corresponding control value.

It has been proposed that, in the guinea-pig, oestradiol acting on a progesterone-primed endometrium stimulates the synthesis of proteins which, by some mechanism, increase the intracellular free calcium concentration and thereby activate $\mathrm{PLA}_{2}$ to release arachidonic acid from phospholipids for increased $\mathrm{PGF}_{2 \alpha}$ synthesis after day 11 of the cycle (see Poyser, 1995). Although oestradiol and progesterone when administered in vivo cause a selective increase in endometrial $\mathrm{PGF}_{2 \alpha}$ synthesis (Poyser, 1983a, b), treatment with oestradiol or progesterone in vitro inhibits the outputs of $\mathrm{PGF}_{2 a}$ and $P G E_{2}$ (but not of 6-keto-PGF ${ }_{1 u}$ ) from guinea-pig endometrium in culture (Riley and Poyser, 1987b). In the present study, oestradiol and progesterone inhibited $\mathrm{PGF}_{2 \alpha}$ output from glandular epithelial cells and $\mathrm{PGE}_{2}$ output from stromal cells after $8 \mathrm{~h}$ of culture. Thus the two steroid hormones inhibit the production of different PGs by the two cell types. This differential inhibition would account for the reduced output of both $\mathrm{PGE}_{2}$ and $\mathrm{PGF}_{2 u}$ from guinea-pig endometrium when cultured in vitro in the presence of either steroid hormone. Progesterone treatment in vitro reduces the outputs of $\mathrm{PGF}_{2 u}$ and $\mathrm{PGE}_{2}$ from both cell types derived from pig endometrium, while oestradiol treatment has no effect (Zhang and Davies, 1991). On bovine epithelial cells, in vitro progesterone treat- ment increases and oestradiol treatment decreases the outputs of $\mathrm{PGF}_{2 \alpha}$ and $\mathrm{PGE}_{2}$. Neither hormone affects the output of $\mathrm{PGF}_{2 \alpha}$ and $\mathrm{PGE}_{2}$ from stromal cells (Asselin et al., 1996). On human endometrial epithelial cells, oestradiol treatment in vitro stimulates $\mathrm{PGF}_{2 \alpha}$ output, and this increase is largely prevented by progesterone (Schatz et al., 1985). These observations, taken together with the findings in the present study, show that there are differences among species regarding the effects of the ovarian steroid hormones in vitro on PG production by the endometrial cell types cultured in vitro.

The administration of actinomycin $D$ into the uterus of sheep and guinea-pigs prevents luteal regression and prolongs the oestrous cycle (French and Casida, 1973; Poyser, 1979). In guinea-pigs, this has been shown to be due to reduced PGF $2 \alpha$ output from the uterus (Poyser and Riley, 1987). Actinomycin D (an inhibitor of DNA-dependent RNA synthesis), cycloheximide (which prevents the movement of ribosomes along mRNA) and puromycin (an inhibitor of polypeptide chain elongation) inhibit protein synthesis by and the outputs of $\mathrm{PGF}_{2 \alpha^{\prime}}, \mathrm{PGE}_{2}$ and 6-keto-PGF ${ }_{1 \alpha}$ from day 7 guinea-pig endometrium in culture (Riley and Poyser, 1987b). However, the effect of cycloheximide at high concentrations (i.e. $50 \mu \mathrm{g}$ $\mathrm{ml}^{-1}$ ) is less marked since this compound also has a short-term 



Phospholipase $\mathrm{A}_{2}$ concentration $\left(\mathrm{U} \mathrm{ml^{-1 }}\right)$

Fig. 1. Effects of cumulative increasing concentrations of phospholipase (PL) $A_{2}$ on the mean \pm SEM $(n=3)$ intracellular free calcium concentration $\left(\left[\mathrm{Ca}^{2+}\right]_{i}\right)$, expressed as a percentage of the 'baseline' concentration in the absence of PLA 2 in glandular epithelial cells $(\square)$ and stromal cells $(\boldsymbol{\square})$ of guinea-pig endometrium on $(a, b)$ day 7 and $(c, d)$ day 15 of the cycle in $(a, c)$ calcium-containing and $(b, d)$ calcium-depleted Krebs' solution. 'Significantly $(P<0.05)$ higher than corresponding baseline value. * Significantly $(P<0.05)$ higher than corresponding value from stromal cells.

stimulatory effect on PG output, especially the output of $\mathrm{PGE}_{2}$ (Matthews and Poyser, 1991). In the present study, the three inhibitors of protein synthesis reduced the outputs of $\mathrm{PGF}_{2 \alpha^{\prime}}$ $\mathrm{PGE}_{2}$ and 6-keto-PGF $\mathrm{F}_{1 a}$ from both glandular epithelial cells and stromal cells. $\mathrm{PGE}_{2}$ output was affected the least, particularly by cycloheximide $\left(50 \mu \mathrm{g} \mathrm{ml}^{-1}\right)$. This finding is in agreement with the observation that cycloheximide at higher concentrations has a stimulatory effect on $\mathrm{PGE}_{2}$ output (Matthews and Poyser, 1991). Nevertheless, the results obtained with actinomycin D, cycloheximide and puromycin indicate that continued protein synthesis is necessary for the maintenance of PG synthesis in both the glandular epithelial cells and stromal cells of guinea-pig endometrium. Which proteins are involved needs further study, but it is known that PGH synthase is destroyed during PG biosynthesis so fresh enzyme has to be provided if the biosynthesis is to be maintained (Lands et al., 1973).

The calcium ionophore A23187 stimulates PG output from the guinea-pig uterus superfused in vitro by a mechanism dependent upon the presence of extracellular calcium (Poyser and Brydon, 1983; Poyser, 1984). A23187 also stimulates $\mathrm{PGF}_{2 a}$ output from guinea-pig endometrium cultured in vitro (Leaver and Seawright, 1982). In the present study, A23187 increased $\mathrm{PGF}_{2 \alpha}$ output from glandular epithelial cells and, to a lesser extent, from stromal cells after $2 \mathrm{~h}$. This differential effect in favour of epithelial cells in the guinea-pig is similar to that seen in humans where A23187 stimulates increased arachidonic acid release and $\mathrm{PGF}_{2 \alpha}$ output from epithelial cells but not from stromal cells (Schatz et al., 1987; Bonney et al., 1991). A23187 did not increase the outputs of $\mathrm{PGE}_{2}$ and 6-keto-PGF ${ }_{1 u}$ from guinea-pig endometrial cells, so the stimulatory action of A23187 via calcium appears to be specific for $\mathrm{PGF}_{2 u}$. The prolonged treatment with A23187 inhibited PGF ${ }_{2 \alpha}$ output from glandular epithelial cells and stromal cells, and 6-keto-PGF 1 iu output from stromal cells. The reason for this inhibitory effect is not known but may be due to a toxic action on the cells during the course of the culture period.

$\mathrm{PLA}_{2}$ increases the outputs of $\mathrm{PGF}_{2 \mathrm{at}^{\prime}} \mathrm{PGE}_{2}$ and 6-keto$\mathrm{PGF}_{1 u}$ from the guinea-pig uterus superfused in vitro (Poyser, 1987). PLA $A_{2}$ has now been found to increase the outputs of these three PGs from both glandular epithelial cells and stromal cells. Thus the action of $\mathrm{PLA}_{2}$ (from Naja naja venom) is not cell specific or prostaglandin specific. PLA $A_{2}$ also increased the intracellular free calcium concentration in both cell types in the presence and absence of extracellular calcium. However, this effect was 10- to 20 -fold greater in the presence of extracellular 
calcium than in its absence, indicating that PLA $A_{2}$ caused a large influx of calcium into the cells as well as causing the release of some intracellular calcium. PLA $\mathrm{A}_{2}$ was equally effective at raising the intracellular free calcium concentration in glandular epithelial cells and stromal cells obtained from day 7 endometrium, but was more effective on glandular epithelial cells than on stromal cells derived from day 15 endometrium. The mechanism by which $\mathrm{PLA}_{2}$ increases the intracellular free calcium concentration in these cells is unknown, but it appears that the stage of the cycle has some influence on this mechanism. The question is raised as to whether PLA $\mathrm{P}_{2}$ releases arachidonic acid for PG synthesis by acting directly on phospholipids, or whether $\mathrm{PLA}_{2}$ acts as a calcium ionophore (like A23187) and activates endogenous $\mathrm{PLA}_{2}$ by increasing the intracellular free calcium concentration.

The action of PLA $\mathrm{A}_{2}$ is unlikely to be due solely to it increasing the free intracellular calcium concentration since (i) $\mathrm{PLA}_{2}$ had a different PG-releasing profile from A23187 and (ii) unlike $\mathrm{A} 23187, \mathrm{PLA}_{2}$ has been found to increase the release of PGs from the superfused guinea-pig uterus in the absence of extracellular calcium (R. S. Scotland, M. G. H. Scott and N. L. Poyser, unpublished observation). These findings suggest that $\mathrm{PLA}_{2}$ acts directly on phospholipids to release arachidonic acid. However, the PG-forming effect of PLA ${ }_{2}$, like that of A23187, is inhibited by the intracellular calcium antagonist, TMB-8 (Poyser, 1985; Johnson and Poyser, 1991). This finding indicates that the action of $\mathrm{PLA}_{2}$ is dependent upon intracellular calcium (with the calcium acting as a co-factor), or that TMB-8 inhibits endometrial PG synthesis by a mechanism other than its ability to inhibit the action of intracellular calcium.

Melittin stimulates endogenous PLA $\mathrm{P}_{2}$ and has been found to increase the output of prostaglandins from the superfused guinea-pig uterus (Johnson and Poyser, 1991) and sheep endometrium in vitro (Lee and Silvia, 1994). Melittin stimulated the outputs of $\mathrm{PGF}_{2 \alpha^{\prime}} \mathrm{PGE}_{2}$ and 6-keto-PGF $\mathrm{PG}_{1 \alpha}$ from glandular epithelial cells but had no effect on stromal cells. Thus the PG-releasing action of melittin is specific for the glandular epithelial cells.

Aristolochic acid is an inhibitor of PLA $A_{2}$ and so prevents the release of arachidonic acid from phospholipids (Rosenthal et al., 1989). Aristocholic acid reduced the output of $\mathrm{PGF}_{20}$ from glandular epithelial cells, suggesting that endogenous PLA $A_{2}$ is involved in the production of $\mathrm{PGF}_{2 \alpha}$ by this cell type. Aristolochic acid has been found to inhibit basal and oxytocininduced $\mathrm{PGF}_{2 \alpha}$ release from sheep endometrium (Lee and Silvia, 1994), indicating that endogenous $\mathrm{PLA}_{2}$ is involved in endometrial $\mathrm{PGF}_{2 t t}$ synthesis in sheep. Aristolochic acid did not inhibit PGF ${ }_{2 \alpha}$ output from stromal cells, or the outputs of $\mathrm{PGE}_{2}$ and 6-keto-PGF $\mathrm{PG}_{1 \alpha}$ from glandular epithelial cells and stromal cells. Thus it is not clear what mechanisms are involved in the release of arachidonic acid for the synthesis of these PGs. In fact, aristolochic acid surprisingly increased $\mathrm{PGE}_{2}$ output from stromal cells during the first $2 \mathrm{~h}$ of culture.

Overall, this study has shown that the glandular epithelial cells, as opposed to stromal cells, are the main cells synthesizing PG in the guinea-pig endometrium. Therefore, it is probable that these cells secrete the $\mathrm{PGF}_{2 a}$ necessary for luteolysis. The present findings indicate that the synthesis of $\mathrm{PGF}_{2 u}$ by these glandular cells depends upon fresh protein synthesis and endogenous $\mathrm{PLA}_{2}$ activity.
The technical assistance of Mrs. Lorna Turnbull is greatly appreciated.

\section{References}

Asselin E, Goff AK, Bergeron H and Fortier MA (1996) Influence of sex steroids on the production of prostaglandin $\mathrm{F}_{2 a}$ and $\mathrm{E}_{2}$ and response to oxytocin in cultured epithelial and stromal cells of the bovine endometrium Biology of Reproduction 54 371-379.

Bonney RC, Beesley IS and Franks S (1991) Release of arachidonic acid from human endometrial cells in culture mediated by calcium ionophore (A23187) or fluoride Journal of Reproduction and Fertility 93 449-460

Buchan KW and Martin W (1991) Bradykinin induces elevation of cytosolic calcium through mobilisation of intracellular and extracellular pools in aortic endothelial cells British Journal of Pharmacology $10234-40$

Butcher RL, Chu KY and Melampy RM (1962) Utero-ovarian relationships in the guinea pig Endocrinology $\mathbf{7 1} 810-815$

Chaminadas G, Propper AY, Rogez M, Prost O, Remy-Martin JP and Adessi GL (1986) Culture of epithelial and stromal cells of guinea-pig endometrium and the effects of oestradiol-17ß on the epithelial cells Journal of Reproduction and Fertility 77 547-558

Danet-Desnoyers C, Wetzels C and Thatcher WW (1994) Natural and recombinant interferon $\tau$ regulate basal and oxytocin-induced secretion of prostaglandin $\mathrm{F}_{2 u}$ and $\mathrm{E}_{2}$ by epithelial cells and stromal cells in the endometrium Reproduction Fertility and Development 6 193-202

French LR and Casida LE (1973) Effect of actinomycin on corpus luteum regression in ewes Journal of Animal Science 37 1218-1221

Grynkiewicz G, Poerie M and Tsien RY (1985) A new generation of $\mathrm{Ca}^{2+}$ indicators with greatly improved fluorescence properties Journal of Biological Chemistry $2603440-3450$

Johnson FA and Poyser NL (1991) Effect of melittin on prostaglandin production by guinea-pig uterus Journal of Reproduction and Fertility 93 577-583

Lands WEM, LeTellier PR and Vanderhoek JY (1973) Inhibition of prostaglandin biosynthesis Advances in the Biosciences 9 15-28

Leaver HA and Poyser NL (1981) Distribution of arachidonic acid and other fatty acids in the lipids of guinea-pig uterus and plasma in relation to uterine prostaglandin synthesis Journal of Reproduction and Fertility 61 325-333

Leaver HA and Seawright A (1982) Control of endometrial prostaglandin output in vitro during the estrous cycle of the guinea pig: influence of estradiol-17ß, progesterone, oxytocin and calcium ionophore A23187 Prostaglandins, Leukotrienes and Medicine 9 657-668

Lee J-S and Silvia WJ (1994) Cellular mechanisms mediating the stimulation of ovine endometrial secretion of prostaglandin $F_{2 u}$ in response to oxytocin: role of phospholipase $\mathrm{A}_{2}$ Journal of Endocrinology 141 491-496

Matthews JS and Poyser NL (1991) Mechanisms involved in the stimulation by cycloheximide of prostaglandin production in the guinea-pig uterus Prostaglandins, Leukotrienes and Essential Fatty Acids 42 261-265

Mitchell S, Poyser NL and Wilson NW (1977) Effect of p-bromophenacyl bromide, an inhibitor of phospholipase $A_{2}$, on arachidonic acid release and prostaglandin synthesis by the guinea-pig uterus British Journal of Pharmacology 59 107-113

Peplow PV and Hurst PR (1989) Prostaglandin synthesis by isolated cells of rat uterus: production rates, and effects of indomethacin and histamine Prostaglandins, Leukotrienes and Essential Fatty Acids 35 51-56

Poyser NL (1979) Effect of actinomycin D on uterine prostaglandin production and oestrous cycle length in guinea-pigs Journal of Reproduction and Fertility $56559-565$

Poyser NL (1983a) Differential stimulation of prostaglandin and thromboxane synthesising capacities of guinea-pig uterus and ovary Prostaglandins, Leukotrienes and Medicine 10 163-177

Poyser NL (1983b) Effect of treating ovariectomized guinea-pigs with estradiol and progesterone on basal and A23187-stimulated release of prostaglandins from the uterus superfused in vitro Prostagiandins, Leukotrienes and Medicine 11 345-360

Poyser NL (1984) The effect of using calcium-free Krebs' solution on basal and A23187-stimulated prostaglandin output from the day 15 guinea-pig uterus superfused in vitro Prostaglandins, Letkotrienes and Medicine 13 259-269

Poyser NL (1985) Effects of TMB-8, an intracellular calcium antagonist, on prostaglandin output from the guinea-pig uterus Journal of Reproduction and Fertility $75 \quad 223-230$ 
Poyser NL (1987) Effects of various factors on prostaglandin synthesis by the guinea-pig uterus Journal of Reproduction and Fertility 91 371-384

Poyser NL (1995) The control of prostaglandin production by the endometrium in relation to luteolysis and menstruation Prostaglandins, Levkotrienes and Essential Fatty Acids 53 147-195

Poyser NL and Brydon LJ (1983) Prostaglandin release from the guinea-pig uterus superfused in vitro. Effect of stage of estrous cycle, progesterone, estradiol and oxytocin Prostaglandins 25 443-456

Poyser NL and Riley SC (1987) Effect of actinomycin D on prostaglandin synthesis by and output from the guinea-pig uterus Prostaglandins, Lenkotrienes and Medicine 28 153-168

Riley SC and Poyser NL (1987a) Prostaglandin production by the guinea-pig endometrium: is calcium necessary? Joumal of Endocrinology 113 463-471

Riley SC and Poyser NL (1987b) Effects of oestradiol, progesterone, hydrocortisone and oxytocin on prostaglandin output from the guinea-pig endometrium maintained in tissue culture Prostaglandins 34 535-551

Riley SC and Poyser NL (1989) Is protein synthesis necessary for prostaglandin production by guinea-pig endometrium? Journal of Reproduction and Fertility $8673-89$
Rosenthal MD, Vishwanath BS and Franson RC (1989) Effects of aristolochic acid on phospholipase $A_{2}$ activity and arachidonate metabolism in human neutrophils Biochimica et Biophysica Acta 1001 1-8

Schatz F, Markiewicz L, Barg P and Gurpide E (1985) In vitro effects of ovarian steroids on prostaglandin $\mathrm{F}_{2 \alpha}$ output by human endometrium and endometrial epithelial cells Journal of Clinical Endocrinology and Metabolism 61 $361-367$

Schatz F, Markiewicz L and Gurpide E (1987) Differential effects of estradiol, arachidonic acid, and $A 23187$ on prostaglandin $F_{2 x}$ output by epithelial and stromal cells of human endometrium Endocrinology 120 1465-1471

Stayaswaroop PG, Bressler RS, de la Pera MM and Gurpide E (1979) Isolation and culture of human endometrial glands Journal of Clinical Endocrinology and Metabolism 48 639-641

Watson ED, Aubrey ES, Zanecosky HG and Sertick PL (1992) Isolation and culture of glandular epithelial and stromal cells from the endometrium of mares Journal of Reproduction and Fertility 95 269-275

Zhang $\mathrm{Z}$ and Davis DL (1991) Prostaglandin $\mathrm{E}$ and $\mathrm{F}_{2 a}$ secretion by glandular and stromal cells of the pig endometrium in vitro - effects of estradiol-17 $\beta$, progesterone, and day of pregnancy Prostaglandins 42 151-162 